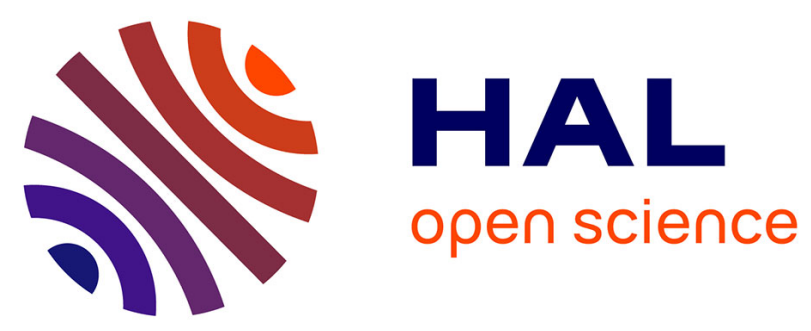

\title{
Performance measurement of a 50-square-meter kite set-up on a 13-meter trawler
}

Morgan Behrel, Kostia Roncin, Damien Grelon, Frédéric Montel, Alain Nême, Jean-Baptiste Leroux, Christian Jochum, Yves Parlier

\section{To cite this version:}

Morgan Behrel, Kostia Roncin, Damien Grelon, Frédéric Montel, Alain Nême, et al.. Performance measurement of a 50-square-meter kite set-up on a 13-meter trawler. La Houille Blanche - Revue internationale de l'eau, 2019, 2019 (5-6), pp.67-69. 10.1051/lhb/2019036 . hal-02431023

\section{HAL Id: hal-02431023 \\ https://hal.science/hal-02431023}

Submitted on 27 Sep 2021

HAL is a multi-disciplinary open access archive for the deposit and dissemination of scientific research documents, whether they are published or not. The documents may come from teaching and research institutions in France or abroad, or from public or private research centers.
L'archive ouverte pluridisciplinaire HAL, est destinée au dépôt et à la diffusion de documents scientifiques de niveau recherche, publiés ou non, émanant des établissements d'enseignement et de recherche français ou étrangers, des laboratoires publics ou privés. 


\title{
Performance measurement of a 50-square-meter kite set-up on a 13-meter trawler
}

\author{
Morgan Behrel ${ }^{1, *}$, Kostia Roncin ${ }^{1}$, Damien Grelon ${ }^{2}$, ${\text { Frédéric } \text { Montel }^{1} \text {, Alain Nême }}^{1}$, \\ Jean-Baptiste Leroux ${ }^{1}$, Christian Jochum ${ }^{1}$ and Yves Parlier $^{3}$ \\ ${ }^{1}$ ENSTA Bretagne, FRE CNRS 3744, IRDL, Brest, France \\ ${ }^{2}$ MERINOV, Grande-Rivère, Quebec, Canada \\ ${ }^{3}$ BEYOND THE SEA ${ }^{\circledR}$, La Teste-de-Buch, France
}

\begin{abstract}
This paper describes an on board measurement campaign held in Grande-Rivière, Gaspésie, Province of Québec, Canada, in October 2015, involving a 13-meter trawler equipped with a 50-squaremeter kite. The aim of the campaign was to access the boat performance when the kite is used for auxiliary propulsion. To achieve this purpose, in addition to the kite control system, a set of sensors was installed. During the trials, runs with kite in static flight were done, with around 12 knots of true wind speed. The data post processing is presented in this paper, and allows an estimate of the lift coefficient and the lift to drag ratio of the kite and the tethers. The collected data are consistent with other experimental data published.
\end{abstract}

Keywords: on board measurements / auxiliary propulsion / kite / sea trials

Résumé - Mesure des performances d'un kite de $\mathbf{5 0}$ mètres carrés installé sur un chalutier de 13 mètres. Cet article décrit une campagne de mesure en mer réalisée sur un chalutier de 13 mètres équipé d'un kite de 50 mètres carrés. Cette campagne s'est déroulée à Grande Rivière, Gaspésie, Province de Québec, Canada, en octobre 2015. Le but était d'évaluer les performances du navire lorsque le kite est déployé. Pour cela, en plus des dispositifs de contrôle du kite, un ensemble de capteurs a été installé. Au cours de la campagne, des phases rectilignes avec le kite fonctionnant en vol statique ont été effectuées, avec environ 12 nœuds de vent réel. Le post-traitement des données qui est présenté permet d'estimer la finesse du kite en vol statique ainsi que son coefficient de portance. Les données obtenues sont cohérentes avec d'autres résultats expérimentaux publiés.

Mots clés : mesures embarquées / propulsion auxiliaire / kite / essais en mer

\section{Introduction}

The current research project, undertaken by the company BEYOND THE SEA ${ }^{\circledast}$, and managed in partnership with ENSTA Bretagne, aims to develop kites as auxiliary propulsion system for ships. In this context, a sea trial and a measurement campaign have been set up in partnership with a Canadian fishing vessel and the Merinov institute, located in Grande-Rivière, Gaspésie, Province of Québec, Canada in October 2015.

The trials were conducted on a 13-meter fishing vessel. These types of vessel (trawler) are particularly suitable for kite-assisted propulsion, because they are operated at low speed, leading to more appropriate relative wind angles.

*Correspondence: morgan . behrel@ensta-bretagne.org
Various structure modifications were carried out to allow the use of a towing kite, especially a reinforcement of the foredeck on which kite tethers were attached. Moreover the boat was already fitted with engine sensors (fuel flow, propeller shaft rotation speed and torque) whereby the measurement of the impact of the kite on the propulsion chain could be carried out.

The kite used during the trials had an area of $50 \mathrm{~m}^{2}\left(34 \mathrm{~m}^{2}\right.$ of projected area), with an inflatable leading edge, and 9 inflatable battens. With this architecture, the kite has its own shape without any aerodynamic load which makes launching and recovering procedures easier. The mass of the deflated kite including bridles is $21 \mathrm{~kg}$.

The measurement system was based on 3 main sensors: a 3D load cell providing orientation and intensity of the forces generated by the kite on the boat, an Inertial Measurement Unit coupled with a GPS device providing boat motion and velocity, 
and an anemometer. The details of the experimental set up can be found in Behrel et al. (2016).

Runs with kite in static flight were carried out. Logged data were used to compute the lift to drag ratio and the lift coefficient of the kite. The presented method is specifically adapted to the collected data. Indeed, due to a lack of information on the kite orientation during flight and on wind along the altitude, strong assumptions and estimations have to be done, leading to results which must be interpreted with caution. However, the obtained lift to drag ratio and lift coefficient make sense with other experimental works like Dadd (2012).

\section{Post-processing of kite flight data}

The aim of the following part is to process data to retrieve the lift to drag ratio of the system \{kite + tethers $\}$. However, to compute the lift to drag ratio, the wind direction at the altitude of the kite needs to be known as it directly affects the orientation of the wind window. In the same way, to compute the lift coefficient, the wind intensity at the kite altitude also needs to be known. Unfortunately, there were no reliable means to measure it. Actually, only the relative wind $\underline{V}_{W R}$ over the boat, at $9 \mathrm{~m}$ over the sea, was measured. The true wind vector $V_{W T}$ at the same location can be easily retrieved using the velocity vector of the measurement point $V_{M}$ (see Eq. (1)), but the true wind at other altitudes can only be estimated. Indeed, the altitude impacts true wind both in terms of strength and direction. With no possibility of getting accurate modelling of the twist of the flow along the altitude, it has been decided to neglect the effect of twist, and only take into account the 2D planar wind distribution profile calculated using the equation (2) (ITTC, 2014). Equations (1)-(3) present the process to obtain the relative wind velocity and boat velocity measurement from relative wind velocity for any altitude $z$.

$$
\begin{gathered}
\underline{V}_{W T}\left(Z_{0}\right)=\underline{V}_{W R}\left(Z_{0}\right)+\underline{V}_{M}, \\
\underline{V}_{W T}(z)=\left(\frac{z}{Z_{0}}\right)^{1 / 7} \underline{V}_{W T}\left(Z_{0}\right), \\
\underline{V}_{W R}(z)=\underline{V}_{W T}(z)-\underline{V}_{A},
\end{gathered}
$$

Where $Z_{0}$ is the altitude measurement and $z$ is the altitude above sea level. $\underline{V}_{A}$ is the velocity of kite attachment point. However, during trials, the velocities induced by ship motions at any points of the ship were observed to stay under $2 \%$ of the ship velocity magnitude. Hence, they were neglected, and $V_{A}$ and $\underline{V}_{M}$ are taken equal to $\underline{V}_{S}$, and $\underline{V}_{S}$ is assumed to be contained in the horizontal plane, as $\underline{V}_{W R}$ consequently.

With the relative wind vector defined for any altitude, we can create a new axis system based on it. The Relative Wind reference frame $R_{W R}$ is defined with the $X$-axis along the relative wind vector at the kite altitude, the $Z$-axis vertical pointing down and the $Y$-axis completing the coordinate system to create a direct one. To process the lift to drag ratio and the lift coefficient, the apparent wind on the kite needs to be known. For the present study, the kite is considered as to be in perfect static flight, with no velocity in the ship reference frame. Therefore, the apparent wind vector is equal to the relative wind vector at the kite altitude.

\subsection{Kite force vector}

The kite force vector $F_{k}$ was measured with the 3D load cell rigidly fixed to the ship, and consequently, the vector is at first expressed in the ship reference frame, denoted with superscript $(s)$. However the following computations require a force vector expressed in the relative wind reference frame $R_{W R}$, which can be done using equation (4):

$$
\underline{F}_{k}^{(W R)}=\underline{\underline{M}}\left(\beta_{W R}, \theta_{s}, \varphi_{s}\right) \underline{F}_{k}^{(s)} .
$$

With the assumptions presented previously, the transfer matrix $\underline{\underline{M}}$ depends on the relative wind angle $\beta_{W R}$, and the attitude angles of the boat $\theta_{s}$ and $\phi_{s}$, respectively the pitch and roll angles. The relative wind angle comes from the construction of the relative wind presented in equation (3). The pitch and roll values are directly measured by the Inertial Measurement Unit.

\subsection{Lift to drag ratio estimation}

From there, it becomes straightforward to compute the lift to drag ratio. Indeed, the component of the force along $\underline{X}_{W R}$ is the total drag and the projection into the $\left(\underline{Y}_{W R}, \underline{Z}_{W R}\right)$ plane is the lift. The component of force along $\underline{Z}_{W R}$ is the sum of the vertical aerodynamic force generated by the kite and the weight $P$ of the kite and tethers. The latter is then subtracted to the vertical component of the measured force to get only the aerodynamic force. Finally the lift to drag ratio is achieved by processing equation (5):

$$
\frac{L}{D}=\frac{\sqrt{F y_{W R}^{2}+\left(F z_{W R}-P\right)^{2}}}{F x_{W R}} .
$$

\subsection{Lift coefficient estimation}

The previous part led to the identification of lift and drag components of kite force, from the measured force expressed in the relative wind axis system. From there, and with the same assumptions, lift coefficient can be processed using equation (6).

$$
C_{L}=\frac{L}{\frac{1}{2} \rho_{a} A_{k} V_{a}^{2}}=\frac{\sqrt{F y_{W R}^{2}+\left(F z_{W R}-P\right)^{2}}}{\frac{1}{2} \rho_{a} A_{k} V_{W R}{ }^{2}} .
$$

The projected kite area $A_{k}$ was used to enable comparison with Dadd (2012). The density of the air $\rho_{a}$ was estimated to $1.22 \mathrm{~kg} \cdot \mathrm{m}^{-3}$ during the measurement day (air temperature $15^{\circ} \mathrm{C}$, atmospheric pressure $1012 \mathrm{hPa}$, relative humidity $70 \%$ ). $V_{a}$ is the kite apparent wind speed, and is equal to the relative wind speed $V_{W R}$ in the specific case of static flight.

\section{Results}

Equations (5) and (6) have been processed for 3 runs with kite in static flight. Results are presented in Table 1. No kite settings were modified during or between periods. The kite position during the second period (P.2) is presented in Figure 1, expressed in relative wind reference frame. 
Table 1. Compiled results of three periods with kite in static flight.

\begin{tabular}{|c|c|c|c|c|c|c|c|}
\hline & \multirow[t]{2}{*}{$\mathrm{RD}$} & \multirow[t]{2}{*}{ TWS } & \multirow[t]{2}{*}{ TWA } & \multicolumn{2}{|c|}{$\mathrm{L} / \mathrm{D}$} & \multicolumn{2}{|c|}{$\mathrm{C}_{\mathrm{L}}$} \\
\hline & & & & $\mathrm{M}$ & SD & $\mathrm{M}$ & $\mathrm{SD}$ \\
\hline P. 1 & 399 & 5.7 & 88 & 5.9 & 2.3 & 0.68 & 0.21 \\
\hline P. 2 & 569 & 6.1 & 95 & 6.1 & 2.5 & 0.76 & 0.26 \\
\hline P. 3 & 209 & 5.7 & 304 & 5.3 & 1.5 & 0.59 & 0.17 \\
\hline
\end{tabular}

$\mathrm{RD}=$ Run duration $(\mathrm{s})$; TWS $=$ True wind speed $(\mathrm{m} / \mathrm{s}) ; \mathrm{TWA}=$ True wind angle relative to boat axis $\left(^{\circ}\right)$; $\mathrm{M}=$ Mean; $\mathrm{SD}=$ Standard deviation.

The average lift to drag ratio during the longest period is equal to 6.1 , and the average lift coefficient is equal to 0.76 . This seems consistent with other experimental data published, like Dadd's ones (2012). Indeed, for a 3-square-meter kite with an aspect ratio AR of 4.9, Dadd got a lift coefficient of 0.78 and a lift to drag ratio of 6.07. To estimate the drag coefficient and thus the lift to drag ratio of other kites with other aspect ratios, Dadd uses the Prandtl's formula as presented in Abbott and Von Doenhoff (1959) and given in equation (7).

$$
C_{D}^{\prime}=C_{D}+\frac{C_{L}^{2}}{\pi}\left(\frac{1}{A R^{\prime}}-\frac{1}{A R}\right) .
$$

Assuming both kites are trimmed to produce the same lift coefficient, and applying this method to the kite used for the present study, whose aspect ratio $A R$ is 5.5 , the expected lift to drag ratio should be 6.28 .

\section{Discussion}

The averaged results of the 3 periods are close, with a good agreement with published data, as it has been shown previously. However, a point-to-point data analysis shows extreme values of lift to drag ratios and lift coefficients that are not realistic. This demonstrates the limits of the various assumptions which have been made, particularly the perfect static flight assumption. Indeed, Figure 1 shows that the kite position during a run is a cloud of points, whereas it should be, theoretically, a single point. The straight-line assumption of the tether could also be a source of uncertainty. The decision to disregard the twist wind flow along the altitude due to a lack of data and models could also be detrimental. Indeed, a fourth period with kite in static flight has been logged, but it had to be discarded due to inconsistent data. One possible explanation is a significant shift between the wind orientation at the measurement point and the wind orientation at the kite position. This eventuality leads us to consider, for future

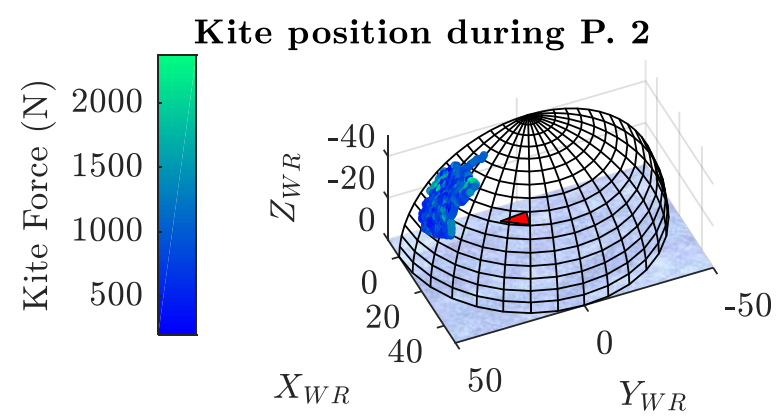

Fig. 1. Kite position and generated force during Period 2, the red triangle denotes the boat position.

experimental campaign, a duplication of wind measurement systems at different altitude. Moreover, the installation of multiple anemometers at various altitudes could also be a good way to improve wind estimation with altitude. This approach has already been undertaken during another experimental campaign, taking place on shore, with the kite control system firmly fixed to the ground. A wind profiler (SODAR type) was used to get the wind intensity and direction along altitude. The results will be presented and discussed in a future paper.

A brief analysis of power can be carried out: the average value of the propulsive force generated by the kite during period 2 is $505 \mathrm{~N}$, for a speed of the boat equals to $2.4 \mathrm{~m} / \mathrm{s}$. The power of the kite is then $1212 \mathrm{~W}$. On the engine side the propeller shaft measurements (rotation speed and torque) led to a transmitted power equals to $38000 \mathrm{~W}$. Assuming a propulsive efficiency of $50 \%$, the kite therefore provided more than $6 \%$ of the propulsive power.

Acknowledgments. The authors wish to express their deep appreciation for the full support of the Steven Paul's masterowner, Guy Leblanc, and his great motivation to innovate. The authors are also grateful to the French agency for energy development and control (ADEME) for the funding of this study.

\section{References}

Abbott IH, Von Doenhoff AE. 1959. Theory of wing sections. Mineola: Dover Publications Inc.

Behrel M, Roncin K, Grelon D, et al. 2016. Presentation of an experimental campaign for measuring performances and effects of a 50-square-meter kite put on a 13-meter trawler. In : $15^{e}$ Journées de l'Hydrodynamique, Brest.

Dadd GM. 2012. Kite dynamics for ship propulsion. Southampton: University of Southampton.

ITTC. 2014. Symbols and terminology list. In : International Towing Tank Conference, Copenhagen. 